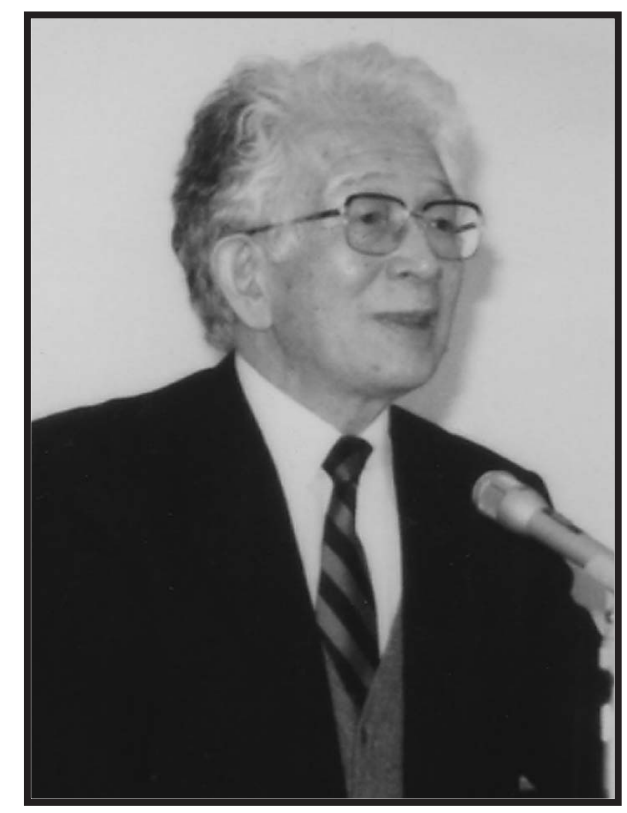

\title{
細辻 豊二先生を悼む
}

日本農薬学会員細辻 豊二先生は平成 15 年 7 月 22 日原 発不明癌により逝去された。大正 13 年 7 月 21 日生まれ, 京都大学農学部農林生物学科植物病研究室を昭和 24 年卒 業，日本農薬株式会社に入社，昭和 33 年同社の農業試験 場長に就任，昭和 39 年には同社系列の室町化成株式会社 取締役，副社長となられた。昭和 43 年日本曹達株式会社 生物研究所の次長に就任, 昭和 45 年理化学研究所生物試 験室に転出，昭和 48 年副主任技師，その間愛媛大学農学 部 (昭和 44 年から), 信州大学繊維学部（昭和 44 年汃 ら), 東京農工大学農学部 (昭和 51 年から), 鳥取大学農 学部 (昭和 52 年から), 東京農業大学農学部（昭和 53 年 から）の講師として作物保護の教育にあたられた。昭和 57 年東京農業大学客員教授となられ, 客員教授定年後も客員 研究員として活躍された。このようにご経歴が多岐にわた り，長年友誼を結ばれた方々も，その折々の片鱗しか存じ あげず一人をもって氏の全貌を記すことは困難であり，多 数の友人知己の思い出を以下にとりま之めた次第である.

氏の大功績といえるのは農薬生物検定法における先駆的 貢献，極微粒化粒剂の実用化，日本農薬学会の設立・発展 への貢献, 国際農薬化学会議の日本開催への貢献であろう.

氏が日本農薬に入社された頃は農薬ビジネスの黎明期で あり，同社で氏が育てあげた生物試験法は農薬界に多大な 影響をもたらした，独創的な諸施設を建設，また水稲二力 メイチュウ防除用茎葉散布 BHC 粒剂を開発されたが，極微 粒化後に崩壊しやすい粒剤とすることによりパラチオン同
様食入幼虫も防除可能となり，この技術は各社の利用する ところとなり，これはまた水田散布用粒剂の唂矢ともなっ た。 また氏らの考案した日本最初のいもち病の接種試験法 「ポット植え苗を用いたイモチ病剂選抜技術」は見里朝正, 淺川 勝氏を通して農業技術研究所にも伝えられ, 後の農 業用抗生物質ブラストサイジン S の開発につながった。農 薬開発全般へのインパクトは大きく, これにより昭和 54 年 度日本農薬学会業績賞（技術）「農薬の効力試験及び粒剂 施用に関する技術開発」を受賞された。 日本曹達は新農薬 創製研究のさらなる発展を期して細辻氏を招いたが，ここ では生物試験の効率向上, 規格化, 自動化を進め, 特に才 リジナルな接種・発病装置と薬剤散布装置の発明を促進さ れた。 日本曹達時代から満井喬氏による理化学研究所イ ンセクトロンの建設を指導・助言され, 理研においては芝 の病害虫防除に力を尽くされた. その一端を細辻・吉田正 義著「原色罒鑑・芝生の病害虫之雑草」（全国農村教育協 会, 昭和 54 年）にみることができる. 氏は常に農薬の効力 の最終的な決め手は生物試験にあることの重要性を説かれ ており, 日本農薬学会内に虫・草・菌の分野の研究者が一 堂に会する農薬生物活性研究会を設立・主宰され, 細辻編 「最新農薬生物検定法」（全国農村教育協会, 昭和 60 年) を発刊された。

日本農薬学会として忘れてならないのは, 熊野義夫, 淺 川 勝氏と共に設立大会開催への事務局を担われ, 学会発 足後屯総務担当の常任評議員, 見里朝正, 山本 出両会長 
時代 2 期にわたり副会長をつとめられ，学会の発展に尽力 されたことである。ささらに昭和 57 年日本で開催予定の国際 農薬化学会議に関しては, 組織委員会が発足するまでの 2 3 年間官公庁, 日本学術会議, 植物保護関連学協会, 企 業を精力的に迴り, 会議運営面の大枠を定め, 組織委員会 が発足後は財務委員長として活躍された。昭和 60 年度の日 本農薬学会功労賞もむべなるかなである.

東京農業大学でははじめ非常勤講師，昭和 57 年よりは客 員教授となられ, 東京農業大学総合研究所研究会農薬部会 の幹事長・幹事として 20 年間にわたり山本 出会長を補 佐，部会の維持発展に尽くされ，また芝草部会でも活躍さ れた。

顧みるに氏の思考のベースは農業現場にあり, 農薬評価 に扔いても考え方なりその手法は一種の泥臭さにあったと いえる，氏の真骨頂は黒子的な立場に徹せられ，また実学
を重んじられたことにある，名より実をとる関西人の典型 であった，次々と新企画を実行されながら出しゃばるといっ たことは全くなく，暖かさ，爽やかさを備えた氏は多くの 人々に愛され，友人仲間では『細やん』の名でとおってい た。実際面，世事に詳しい氏であったが，勝負事に興味を 示さず，ゴルフ場の芝の世話はしながら自らゴルフはせず， スポーツ音痴であったとの逸話もある．はじめに井戸を掘っ た細辻先生に，その水の恩恵を受けたものの一人として心 から感謝し, ご冥福を祈るものである.

山本出

（荒木不二夫, 淺川 勝, 原田達夫, 松中昭一, 満井 喬, 村田道雄, 西久保秀男, 佐野慎亮, 安田 康の諸氏の協力 をえました.) 